\title{
Soybean cultivar BR-16-AHAS tolerance to the herbicide imazapyr
}

\author{
Tammy Aparecida Manabe Kiihl ${ }^{(1)}$ and Carlos Alberto Arrabal Arias ${ }^{(2)}$
}

(1)Centro de Análise e Pesquisa Tecnológica do Agronegócio de Grãos e Fibras, Instituto Agronômico, Caixa Postal 28, CEP 13075-730 Campinas, SP, Brazil. E-mail: tammy@iac.sp.gov.br (2)Embrapa Soja, Caixa Postal 231, CEP 86001-970 Londrina, PR, Brazil. E-mail: arias@cnpso.embrapa.br

\begin{abstract}
The objective of this work was to evaluate the effect of the transgenic soybean BR-16-AHAS genetic constitution on the tolerance to the herbicide imazapyr. BR-16-AHAS was crossed with ten other genotypes. The experimental design was a complete randomized block, in a 2x12x3 factorial arrangement, with two sowing periods (winter and summer), twelve crossing groups and three plant positions (upper, mid and lower), with three replicates. The plants were treated with $100 \mathrm{~g} \mathrm{ha}^{-1}$ a.i. of imazapyr at the V3/V4 stage. For each position of the plant (upper, mid and lower), the following variables were assessed: number of pods, number of seeds, seed weight, number of seeds per pod and the 100 seeds weight. The effect of the herbicide varied according to the more affected plant position (upper, mid and lower) of each genotype. The use of the same gene ahas of BR-16-AHAS, in various genotypes, results in materials with good tolerance to imazapyr; tolerance levels depend not only on the ahas gene, but also on the presence of other genes.
\end{abstract}

Index terms: Arabidopsis thaliana, Glycine max, epistasis, genetic transformation.

\section{Tolerância da soja BR-16-AHAS ao herbicida imazapyr}

Resumo-O objetivo deste trabalho foi avaliar o efeito da constituição genética da soja transgênica BR-16-AHAS sobre a tolerância ao herbicida imazapyr. Dez genótipos foram cruzados com BR-16-AHAS. O delineamento experimental foi o de blocos completos ao acaso, em esquema fatorial $2 \times 12 \times 3$, com dois períodos de semeadura (inverno e verão), doze grupos de cruzamentos de plantas e três posições (superior, médio e inferior), com três repetições. As plantas foram submetidas ao tratamento com imazapyr, $100 \mathrm{~g} \mathrm{ha}^{-1}$ do i.a., nos estádios V3 e V4. Para cada posição da planta (superior, médio e inferior), foram avaliados: número de vagens, número de sementes, peso de sementes, número de sementes por vagem e peso de 100 sementes. Os efeitos do herbicida variaram quanto à posição da planta (alta, média e baixa) mais afetada em cada genótipo. $\mathrm{O}$ uso do mesmo gene ahas da BR-16-AHAS, em diferentes genótipos, resulta em materiais com boa tolerância ao imazapyr. O nível de tolerância depende não só do gene ahas, mas também da presença de outros genes.

Termos para indexação: Arabidopsis thaliana, Glycine max, epistasia, transformação genética.

\section{Introduction}

Agricultural research and development are basic requirements to increase agricultural yield and improve food quality. There are several ways to sustainable increase of yield, such as using of chemical products (fertilizers and pesticides), organic manure, integrated pest control, natural resource conservation and improved varieties which can be obtained by traditional methods or by biotechnology (Herrera-Estrella, 1999). Among the biotechnological techniques available, the most promising is the development of genetically modified organisms (GMO). The creation of genetic combination that does not exist in nature, and specially gene transference between reproductive distinct species, can result in better quality plants, resistant to diseases or herbicides.

Herbicide tolerance is normally a characteristic governed by few genes and this simplifies the development of resistant transgenic varieties. The increase in the number of efficient alternatives for weed control, affecting only the infesting species without harming the development of the commercial variety, is very advantageous for the producers (Hain \& Schreier, 1995).

The first plant into which a bacterial gene was introduced was obtained in 1983, coding for resistance to the antibiotic kanamycin. The gene was introduced by Agrobacterium tumefaciens, in tobacco plants (Frizzas et al., 2004). In soybean, one of the first applications of 
genetic engineering was the development of tolerance to glyphosate (Padgette et al., 1995). Later, other transgenic plants as soybean, rice, cotton, potato, rape seed, sugarcane, corn, eucalyptus and pine were obtained (Vargas et al., 1999; Monquero, 2005).

Aragão et al. (2000) obtained soybean plants tolerant to imazapyr herbicide, where a mutant ahas gene, isolated from Arabidopsis thaliana, was inserted by biobalistics, conferring tolerance to this product. Imazapyr is a wide spectrum herbicide, which controls most of the annual and perennial grasses and also broadleaf species (Beardmore et al., 1991). This herbicide belongs to the chemical group of imidazolinones, which inhibit the AHAS enzyme (acetohydroxyacid synthase EC 4.1.3.18) that acts in the biosynthesis of the branched chain amino acids (valine, leucine and isoleucine), and can lead to plant death. AHAS-inhibiting herbicides are largely used, because of their low toxicity to animals and high efficiency at low dosage (Vargas et al., 1999).

Kiihl \& Arias (2004) compared the performance of conventional genotypes nontreated with imazapyr herbicide to AHAS-treated genotypes and evaluated the effect of imazapyr treatment on BR-16-AHAS and Doko-AHAS events. They observed that BR-16-AHAS genotype was much more affected by imazapyr than Doko-AHAS, when compared to the respective conventional cultivars, besides, the perception of the herbicide effect differed, mainly for most affected plant position (upper, mid and lower), in each genotype. The question that arose after these observations was whether this different response was due to problems of gene expression or to the genetic background of these materials.

The objective of this work was to assess the effect of the genetic constitution of BR-16-AHAS on the tolerance to the herbicide imazapyr.

\section{Materials and Methods}

Ten soybean cultivars including BRS 133, Conquista, Celeste, Jataí, Chapadão, EMG 308, FT 106, E96 125, Uirapuru and Pintado were crossed with BR-16-AHAS (each cross represented one group), and some $\mathrm{F}_{5}$ descendent lines were selected. Three lines were selected within each group, except for two groups where four lines were selected. The treatments consisted of groups of crosses between commercial cultivars and BR-16-AHAS, treated with the herbicide. BR-16-AHAS and Doko-AHAS were used as control group.

The selected lines were sown and assessed in two sowing periods, June 2001 (winter) and December 2001 (summer). The experiments were carried out in greenhouse and the plants were cultivated in 23 tall plastic pots containing $8 \mathrm{~L}$ of substrate. The substrate consisted of a mixture of $20 \%$ sand and $20 \%$ organic compost. Fertilizer was applied according to the substrate analysis. Nitrogen was not used and inoculation with Bradyrhizobium japonicum was performed. Seeds were placed in a germinator and transplanted at the fourth day.

Fifteen days after transplant, the plants were treated with the herbicide imazapyr (100 $\mathrm{g} \mathrm{ha}^{-1}$ a.i. $)$ at the V3/V4 stages. The herbicide was applied with hand-held sprayer. For the application, the pots were separated and later reassembled to the original positions. Extra light was supplied in the winter experiment up to July.

The experimental design was a complete randomized block, distributed in a $2 \times 12 \times 3$ factorial arrangement, with two sowing periods (winter and summer), twelve crossing groups and three plant positions (upper, mid and lower), with three replicates. The plot consisted of one pot, with two plants per pot. After maturation, the plants were divided into thirds and, for each position of the plant (upper, mid and lower), the following variables were assessed: number of pods, number of seeds, seed weight, number of seeds per pod, and 100 seeds weight. Individual analyses of variance were performed for each sowing period $\mathrm{x}$ group combination. In order to verify the effect of plant position, a joint analysis of variance was performed for sowing periods, ascertaining group effects. The means were compared by Tukey's test, at $5 \%$ of probability.

\section{Results and Discussion}

There was sowing period effect for most of the traits, except for 100 seeds weight (Table 1). Almost all groups presented superior means, in the summer, for most of the traits, except for the number of pods in the 'Conquista' group and the 100 seeds weight in 'Chapadão', 'Emgopa 308' and 'Uirapuru' groups (Table 2). The following factors were significant $(p<0.01)$ for all traits: group, sowing period $\mathrm{x}$ group interaction, the line within group and the sowing 
period $\mathrm{x}$ line interaction (Table 1). In the first part of the analysis, for which the effect of plant position was not considered, it was observed that the groups and the lines within each group differed regarding trait expression, and that there was differential genotype response to variations in the sowing period (Table 2).

There was significance $(\mathrm{p}<0.01)$ for the effect of plant position for all traits, for the effect of double interactions (sowing period $\mathrm{x}$ plant position, group $\mathrm{x}$ plant position and line $\mathrm{x}$ plant position) for the traits number of pods, number of seeds, and seed weight and the sowing period $\mathrm{x}$ plant position interaction for number of seeds per pod. There was no significance regarding traits for the triple interactions (sowing period $\mathrm{x}$ group $\mathrm{x}$ plant position, and sowing period $\mathrm{x}$ line $\mathrm{x}$ plant position).
In order to simplify the comparison among the genetic groups, the traits number of pods, number of seeds and weight were represented in percent and compared to the plant total (Table 3). Differences were observed among the groups and within plant positions, mainly in the winter. For example, 'BR-16-AHAS' concentrated $12.5 \%$ of the pods in the upper part, and $48.2 \%$ in the lower part, in the winter experiment, when the herbicide was applied; 'Conquista' concentrated $31 \%$ in the upper part, and $30 \%$ in the lower part. In the summer, the line group performance for the number of pods, number of seeds and weight differed from the performance observed in the winter, showing once again that there was sowing period difference, therefore, the genotype assessment period should be taken into account, in order to obtain good results when distinguishing genotypes with good acceptability for

Table 1. Mean squares obtained in the analyses of variance for number of pods (Np), number of seeds (Ns), seed weight (W, g), number of seeds per pod (Nsp), and of 100 seeds weight (W100, g) assessed for each group derived from conventional soybean cultivars, evaluated after sowing in winter and summer, in greenhouse.

\begin{tabular}{|c|c|c|c|c|c|c|}
\hline Source of variation & $\mathrm{df}$ & $\mathrm{Np}$ & Ns & $\mathrm{W}$ & Nsp & W100 \\
\hline Sowing period (SP) & 1 & $10,380.2 * *$ & $54,082.5^{* *}$ & $1,844.8^{* *}$ & $2.19^{* *}$ & $0.02^{\mathrm{ns}}$ \\
\hline Block/SP & 4 & 165.9 & 405.1 & 2.9 & 0.14 & 23.83 \\
\hline Group (G) & 11 & $545.5^{* *}$ & $2,845.8^{* *}$ & $57.2 * *$ & $0.57 * *$ & $125.54 * *$ \\
\hline SPxG & 11 & $381.4^{* *}$ & $1,409.3 * *$ & $36.1 * *$ & $0.47 * *$ & $15.34 * *$ \\
\hline Lines/group (L/G) & 22 & $208.2 * *$ & $1,237.2 * *$ & $18.8^{* *}$ & $0.29 * *$ & $79.97 * *$ \\
\hline SPxL/G & 22 & $110.4^{* *}$ & $512.6^{* *}$ & $11.3 * *$ & $0.13 * *$ & $36.00 * *$ \\
\hline Position (P) & 2 & $2,138.2 * *$ & $9,066.1 * *$ & $297.2 * *$ & $1.23 * *$ & $191.93 * *$ \\
\hline SPxP & 2 & $2,159.9 * *$ & $11,180.4^{* *}$ & $392.4 * *$ & $0.53 * *$ & $2.39^{\mathrm{ns}}$ \\
\hline $\mathrm{GxP}$ & 22 & $263.1^{* *}$ & $1,018.7 * *$ & $33.2 * *$ & $0.05^{\mathrm{ns}}$ & $2.56^{\mathrm{ns}}$ \\
\hline $\mathrm{LxP} / \mathrm{G}$ & 44 & $103.1 * *$ & $417.4^{* *}$ & $13.7 * *$ & $0.05^{\mathrm{ns}}$ & $1.53^{\mathrm{ns}}$ \\
\hline SPxGxP & 22 & $69.4^{\mathrm{ns}}$ & $287.9^{\mathrm{ns}}$ & $8.8^{\text {ns }}$ & $0.03^{\mathrm{ns}}$ & $1.71^{\mathrm{ns}}$ \\
\hline SPxLxP/G & 44 & $57.2^{\mathrm{ns}}$ & $263.7^{\mathrm{ns}}$ & $6.9^{\text {ns }}$ & $0.03^{\mathrm{ns}}$ & $1.86^{\mathrm{ns}}$ \\
\hline Error & 401 & 56.6 & 239.0 & 7.3 & 0.05 & 4.76 \\
\hline Mean & & 23.7 & 47.1 & 8.3 & 1.9 & 18.19 \\
\hline CV (\%) & & 31.7 & 32.8 & 32.7 & 10.9 & 11.99 \\
\hline
\end{tabular}

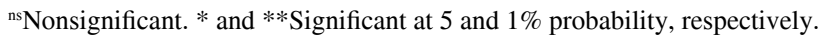

Table 2. Effect of sowing period (winter and summer) on the number of pods, number of seeds, seed weight, number of seeds per pod and 100 seeds weight, evaluated in $\mathrm{F}_{5}$ lines of group of crosses of BR-16-AHAS x commercial soybean cultivars.

\begin{tabular}{|c|c|c|c|c|c|c|c|c|c|c|}
\hline \multirow[t]{2}{*}{ Group } & \multicolumn{2}{|c|}{ No. of pods } & \multicolumn{2}{|c|}{ No. of seeds } & \multicolumn{2}{|c|}{ Seed weight $(\mathrm{g})$} & \multicolumn{2}{|c|}{ No. of seeds per pod } & \multicolumn{2}{|c|}{100 seeds weight $(\mathrm{g})$} \\
\hline & Winter & Summer & Winter & Summer & Winter & Summer & Winter & Summer & Winter & Summer \\
\hline BR-16-AHAS & $18.7 \mathrm{ABa}$ & $17.4 \mathrm{Ea}$ & $30.2 \mathrm{C} \mathrm{a}$ & $37.9 \mathrm{Ga}$ & $5.7 \mathrm{CDb}$ & 7.9Da & $1.6 \mathrm{~Eb}$ & $2.2 \mathrm{ABa}$ & $20.2 \mathrm{Aa}$ & $21.2 \mathrm{Aa}$ \\
\hline Doko-AHAS & $19.4 \mathrm{ABb}$ & $36.8 \mathrm{Aa}$ & $40.3 \mathrm{ABCb}$ & 73.6ABa & 7.5ABb & 13.7Aa & $2.1 \mathrm{ABa}$ & 2.0BCDa & 19.2ABCa & 18.6BCDa \\
\hline BRS 133 & $18.6 \mathrm{ABa}$ & 20.3DEa & $32.6 \mathrm{BCb}$ & 41.7FGa & 6.0BCDb & 8.4CDa & $1.7 \mathrm{~Eb}$ & 2.0ABCa & $19.6 \mathrm{ABa}$ & $20.2 \mathrm{ABa}$ \\
\hline Conquista & $17.0 \mathrm{Bb}$ & 25.3BCDEa & $36.5 \mathrm{ABCb}$ & 51.2CDEFGa & 7.1ABCDb & 10.9ABCDa & 2.1Aa & 2.0BCDb & 20.1Aa & $21.4 \mathrm{Aa}$ \\
\hline Celeste & $19.2 \mathrm{ABb}$ & $38.4 \mathrm{Aa}$ & $35.8 \mathrm{ABCb}$ & 79.6Aa & $5.5 \mathrm{Db}$ & $12.6 \mathrm{ABa}$ & $1.8 \mathrm{CDEb}$ & 2.1ABCa & 17.4CDEb & 16.6DEa \\
\hline Jataí & $20.9 \mathrm{ABb}$ & 29.6ABCDa & $38.3 \mathrm{ABCb}$ & 59.4BCDEFa & 6.1ABCDb & 10.1BCDa & 1.7DEb & 2.0ABCDa & 16.7DEa & 17.1CDEa \\
\hline Chapadão & $21.5 \mathrm{ABa}$ & 23.6CDEa & $35.7 \mathrm{ABCb}$ & 44.1EFGa & 6.2ABCDb & $7.5 \mathrm{Da}$ & $1.6 \mathrm{~Eb}$ & $1.8 \mathrm{Da}$ & 18.6ABCDa & 17.4CDEb \\
\hline EMG 308 & $20.2 \mathrm{ABb}$ & $29.4 \mathrm{ABa}$ & $41.6 \mathrm{ABb}$ & 65.6ABCDa & 7.3ABCb & 10.9ABCDa & $2.0 \mathrm{ABCb}$ & $2.2 \mathrm{Aa}$ & 17.5BCDEa & 16.6DEb \\
\hline FT 106 & $19.9 \mathrm{ABb}$ & 33.6ABa & $42.0 \mathrm{ABb}$ & 68.6ABCa & 6.4ABCDb & 10.8ABCDa & $2.1 \mathrm{ABa}$ & 2.0ABCa & $15.4 \mathrm{Ea}$ & $16.2 \mathrm{Ea}$ \\
\hline E96 125 & $19.5 \mathrm{ABb}$ & 26.4BCDEa & $39.1 \mathrm{ABCb}$ & 52.4CDEFGa & 6.7ABCDb & $8.8 \mathrm{CDa}$ & 2.0ABCa & 2.0BCDa & 17.6BCDEa & 16.8CDEa \\
\hline Uirapuru & $18.2 \mathrm{ABb}$ & 24.1BCDEa & $35.0 \mathrm{ABCb}$ & 48.7DEFGa & $6.5 \mathrm{ABCDb}$ & $8.2 \mathrm{Da}$ & 1.9BCDa & 2.0ABCDa & $19.4 \mathrm{ABCa}$ & $17.7 \mathrm{CDb}$ \\
\hline Pintado & $22.8 \mathrm{Ab}$ & $32.0 \mathrm{ABCa}$ & $45.0 \mathrm{Ab}$ & 61.9ABCDEa & $7.8 \mathrm{Ab}$ & $11.8 \mathrm{ABCa}$ & 2.0ABCa & $1.9 \mathrm{CDa}$ & 17.6BCDb & $19.1 \mathrm{ABCa}$ \\
\hline
\end{tabular}

${ }^{(1)}$ Means followed by the same capital letters in a column and by the same small letters in a line do not differ by Tukey's test, at $5 \%$ probability. 
the ahas gene. The herbicide effects varied according to the most affected plant positions in each genotype; some genotypes showed pod distribution on the plant similar to distribution in Doko-AHAS (e.g. Conquista, Celeste, EMG 308, FT106, E96 125, Uirapuru, and Pintado), and others were more similar to BR-16-AHAS (e.g. BRS 133, Jataí, and Chapadão).

Kiihl \& Arias (2004) found significant differences between Doko-AHAS and BR-16-AHAS for the capacity to produce pods on plants upper part, both in the winter and in the summer. A possible cause for this effect could be related to the insertion point of the ahas gene in BR-16, which would be unsuitable for allowing good levels of expression and for conferring tolerance to the plants. This hypothesis can be now discarded, because using the same gene as BR-16-AHAS in various genotypes, the materials obtained presented tolerance comparable or even superior to Doko-AHAS. Thus, the tolerance levels shown by the various genotypes tested depended not only on the ahas gene, but also on the presence of other genes, characterizing a type of epistasis. Lines within the groups, considered promising, may or may not inherit these additional genes. Nevertheless, lines within the groups, considered nonpromising, may arise gene combinations favorable to increase imazapyr tolerance level, indicating that it may be a polygenic heredity, which has been called genetic constitution or genetic background in this work.

Table 3. Means of each group of crosses of BR-16-AHAS x commercial soybean cultivars, for each plant position, for number of pods, number of seeds, seed weight, number of seeds per pod, and 100 seeds weight, evaluated after sowing in winter (w) and summer (s) in a greenhouse(1).

\begin{tabular}{|c|c|c|c|c|c|c|c|c|c|c|c|}
\hline \multirow[t]{2}{*}{ Group } & \multirow{2}{*}{$\begin{array}{l}\text { Plant } \\
\text { position }\end{array}$} & \multicolumn{2}{|c|}{ No. of pods $(\%)$} & \multicolumn{2}{|c|}{ No. of seeds (\%) } & \multicolumn{2}{|c|}{ Seed weight (\%) } & \multicolumn{2}{|c|}{ No. of seeds per pod } & \multicolumn{2}{|c|}{100 seeds weight $(\mathrm{g})$} \\
\hline & & $\mathrm{W}$ & $\mathrm{s}$ & $\mathrm{w}$ & $\mathrm{S}$ & w & $\mathrm{s}$ & $\mathrm{w}$ & $\mathrm{s}$ & w & $\mathrm{s}$ \\
\hline \multirow[t]{3}{*}{ BR-16-AHAS } & Upper & $12.5 b$ & $26.80 \mathrm{a}$ & $11.77 \mathrm{~b}$ & $27.38 \mathrm{a}$ & $11.85 b$ & $30.08 \mathrm{a}$ & $1.63 \mathrm{a}$ & $2.22 \mathrm{a}$ & $19.69 \mathrm{a}$ & $22.96 \mathrm{a}$ \\
\hline & Mid & $39.3 \mathrm{ab}$ & $37.40 \mathrm{a}$ & $40.44 \mathrm{ab}$ & $38.06 \mathrm{a}$ & $40.28 \mathrm{a}$ & $37.94 \mathrm{a}$ & $1.66 \mathrm{a}$ & $2.24 \mathrm{a}$ & $20.96 \mathrm{a}$ & $21.06 \mathrm{a}$ \\
\hline & Lower & $48.2 \mathrm{a}$ & $35.70 \mathrm{a}$ & $47.78 \mathrm{a}$ & $34.55 \mathrm{a}$ & $47.87 \mathrm{a}$ & $31.99 \mathrm{a}$ & $1.61 \mathrm{a}$ & $2.10 \mathrm{a}$ & $19.85 \mathrm{a}$ & $19.23 \mathrm{a}$ \\
\hline \multirow[t]{3}{*}{ Doko-AHAS } & Upper & $26.57 \mathrm{a}$ & $41.02 \mathrm{a}$ & $25.66 \mathrm{a}$ & $42.04 \mathrm{a}$ & $27.65 a$ & $42.04 \mathrm{a}$ & $2.00 \mathrm{a}$ & $2.05 \mathrm{a}$ & $20.34 \mathrm{a}$ & $\overline{18.79 a}$ \\
\hline & Mid & $41.43 \mathrm{a}$ & $42.53 \mathrm{a}$ & $43.31 \mathrm{a}$ & $42.42 \mathrm{a}$ & $43.19 \mathrm{a}$ & $43.14 \mathrm{a}$ & $2.19 \mathrm{a}$ & $2.00 \mathrm{a}$ & $18.61 \mathrm{a}$ & $18.94 \mathrm{a}$ \\
\hline & Lower & $32.00 \mathrm{a}$ & $16.44 b$ & $31.03 \mathrm{a}$ & $15.55 \mathrm{~b}$ & $29.16 \mathrm{a}$ & $14.82 \mathrm{~b}$ & $1.97 \mathrm{a}$ & $1.90 \mathrm{a}$ & $18.59 \mathrm{a}$ & $17.94 \mathrm{a}$ \\
\hline \multirow[t]{3}{*}{$\overline{\mathrm{BRS}} 133$} & Upper & $17.22 \mathrm{~b}$ & $31.62 \mathrm{a}$ & $16.93 b$ & $32.18 \mathrm{a}$ & $18.45 \mathrm{c}$ & $33.45 \mathrm{a}$ & $1.66 \mathrm{a}$ & $2.05 a$ & $21.21 \mathrm{a}$ & $21.51 \mathrm{a}$ \\
\hline & Mid & $45.15 \mathrm{a}$ & $36.21 \mathrm{a}$ & $45.71 \mathrm{a}$ & $36.61 \mathrm{a}$ & $45.88 \mathrm{a}$ & $36.20 \mathrm{a}$ & $1.68 \mathrm{a}$ & $2.11 \mathrm{a}$ & $19.53 \mathrm{ab}$ & $19.88 \mathrm{ab}$ \\
\hline & Lower & $37.63 \mathrm{a}$ & $32.17 \mathrm{a}$ & $37.36 \mathrm{a}$ & $31.21 \mathrm{a}$ & $35.67 \mathrm{~b}$ & $30.15 \mathrm{a}$ & $1.73 \mathrm{a}$ & $1.96 \mathrm{a}$ & $18.06 \mathrm{~b}$ & $19.16 \mathrm{~b}$ \\
\hline \multirow[t]{3}{*}{ Conquista } & Upper & $31.21 \mathrm{a}$ & $42.08 \mathrm{a}$ & $32.39 \mathrm{ab}$ & $44.05 \mathrm{a}$ & $34.69 a$ & $45.60 \mathrm{a}$ & $2.24 \mathrm{a}$ & $2.14 \mathrm{a}$ & $21.04 \mathrm{a}$ & $22.04 \mathrm{a}$ \\
\hline & Mid & $38.06 \mathrm{a}$ & $33.61 \mathrm{ab}$ & $38.71 \mathrm{a}$ & $33.12 \mathrm{ab}$ & $37.99 a$ & $32.45 \mathrm{ab}$ & $2.16 \mathrm{a}$ & $1.98 \mathrm{ab}$ & $19.47 \mathrm{a}$ & $20.79 a$ \\
\hline & Lower & $30.73 \mathrm{a}$ & $24.31 \mathrm{~b}$ & $28.89 \mathrm{~b}$ & $22.83 b$ & $27.32 b$ & $21.94 b$ & $1.98 \mathrm{~b}$ & $1.81 \mathrm{~b}$ & $19.75 \mathrm{a}$ & $21.23 \mathrm{a}$ \\
\hline \multirow[t]{3}{*}{ Celeste } & Upper & $22.84 b$ & $33.96 \mathrm{a}$ & $23.61 b$ & $34.42 \mathrm{a}$ & $23.97 \mathrm{~b}$ & $35.16 \mathrm{a}$ & $1.85 \mathrm{a}$ & $2.07 \mathrm{a}$ & $17.77 \mathrm{a}$ & $17.73 a$ \\
\hline & Mid & $42.67 \mathrm{a}$ & $34.88 \mathrm{a}$ & $44.80 \mathrm{a}$ & $35.12 \mathrm{a}$ & $42.43 a$ & $34.16 \mathrm{a}$ & $1.88 \mathrm{a}$ & $2.11 \mathrm{a}$ & $17.76 \mathrm{a}$ & $16.28 \mathrm{a}$ \\
\hline & Lower & $34.49 \mathrm{a}$ & $31.16 \mathrm{a}$ & $31.60 \mathrm{~b}$ & $30.46 a$ & $33.60 \mathrm{ab}$ & $30.68 \mathrm{a}$ & $1.74 \mathrm{a}$ & $2.03 \mathrm{a}$ & $16.70 \mathrm{a}$ & $15.79 \mathrm{a}$ \\
\hline \multirow[t]{3}{*}{ Jataí } & Upper & $19.11 b$ & $31.31 \mathrm{a}$ & $19.06 \mathrm{~b}$ & $32.84 \mathrm{a}$ & $20.12 \mathrm{c}$ & $35.53 \mathrm{a}$ & $1.66 \mathrm{a}$ & $2.11 \mathrm{a}$ & $16.61 \mathrm{ab}$ & $18.43 \mathrm{a}$ \\
\hline & Mid & $44.60 \mathrm{a}$ & $34.63 a$ & $45.14 \mathrm{a}$ & $35.48 \mathrm{a}$ & $46.40 \mathrm{a}$ & $35.17 \mathrm{a}$ & $1.76 \mathrm{a}$ & $2.07 \mathrm{a}$ & $17.36 \mathrm{a}$ & $16.99 \mathrm{ab}$ \\
\hline & Lower & $36.29 \mathrm{a}$ & $34.06 \mathrm{a}$ & $35.80 \mathrm{a}$ & $31.68 \mathrm{a}$ & $33.48 \mathrm{~b}$ & $29.30 \mathrm{a}$ & $1.80 \mathrm{a}$ & $1.87 \mathrm{a}$ & $16.09 \mathrm{~b}$ & $15.92 b$ \\
\hline \multirow{3}{*}{ Chapadão } & Upper & $13.45 b$ & $28.76 a$ & $13.24 b$ & $30.27 \mathrm{a}$ & $15.05 \mathrm{~b}$ & $31.61 \mathrm{a}$ & $1.63 \mathrm{a}$ & $1.97 \mathrm{a}$ & $20.22 \mathrm{a}$ & $\overline{18.70 \mathrm{a}}$ \\
\hline & Mid & $44.56 a$ & $32.84 \mathrm{a}$ & $45.33 \mathrm{a}$ & $32.87 \mathrm{a}$ & $45.78 \mathrm{a}$ & $33.30 \mathrm{a}$ & $1.65 \mathrm{a}$ & $1.85 \mathrm{a}$ & $18.40 \mathrm{a}$ & $17.02 \mathrm{a}$ \\
\hline & Lower & $41.99 \mathrm{a}$ & $38.40 \mathrm{a}$ & $41.43 \mathrm{a}$ & $36.86 \mathrm{a}$ & $39.17 \mathrm{a}$ & $35.09 \mathrm{a}$ & $1.60 \mathrm{a}$ & $1.60 \mathrm{a}$ & $17.12 \mathrm{a}$ & $16.27 \mathrm{a}$ \\
\hline \multirow[t]{3}{*}{ EMG 308} & Upper & $26.53 b$ & $43.50 \mathrm{a}$ & $24.55 b$ & $45.27 \mathrm{a}$ & $25.49 b$ & $46.21 \mathrm{a}$ & $1.86 \mathrm{a}$ & $2.35 \mathrm{a}$ & $18.38 \mathrm{a}$ & $17.45 \mathrm{a}$ \\
\hline & Mid & $50.51 \mathrm{a}$ & $36.44 a$ & $51.47 \mathrm{a}$ & $36.40 \mathrm{a}$ & $50.85 \mathrm{a}$ & $35.43 \mathrm{a}$ & $2.10 \mathrm{a}$ & $2.24 \mathrm{a}$ & $17.31 \mathrm{ab}$ & $16.19 \mathrm{a}$ \\
\hline & Lower & $22.96 \mathrm{~b}$ & $20.05 \mathrm{~b}$ & $23.98 b$ & $18.33 \mathrm{~b}$ & $23.66 \mathrm{~b}$ & $18.36 \mathrm{~b}$ & $1.93 \mathrm{a}$ & $2.04 \mathrm{~b}$ & $16.86 \mathrm{~b}$ & $16.19 \mathrm{a}$ \\
\hline \multirow[t]{3}{*}{ FT 106} & Upper & $27.32 b$ & $31.74 a$ & $27.65 b$ & $34.09 \mathrm{a}$ & $28.92 b$ & $36.06 \mathrm{a}$ & $2.11 \mathrm{a}$ & $2.19 \mathrm{a}$ & $16.13 a$ & $17.62 \mathrm{a}$ \\
\hline & Mid & $40.99 a$ & $34.16 a$ & $41.33 \mathrm{a}$ & $34.41 \mathrm{a}$ & $41.49 \mathrm{a}$ & $33.52 \mathrm{a}$ & $2.15 a$ & $2.06 \mathrm{a}$ & $15.41 \mathrm{ab}$ & $15.61 \mathrm{a}$ \\
\hline & Lower & $31.69 \mathrm{~b}$ & $34.11 \mathrm{a}$ & $31.02 \mathrm{~b}$ & $31.50 \mathrm{a}$ & $29.60 \mathrm{~b}$ & $30.42 \mathrm{a}$ & $2.03 \mathrm{a}$ & $1.86 \mathrm{~b}$ & $15.45 \mathrm{~b}$ & $14.69 \mathrm{a}$ \\
\hline \multirow[t]{3}{*}{ E96125 } & Upper & $26.59 \mathrm{~b}$ & $36.64 a$ & $26.14 b$ & $38.76 a$ & $28.24 b$ & $40.88 \mathrm{a}$ & $2.00 \mathrm{a}$ & $2.12 \mathrm{a}$ & $18.77 \mathrm{a}$ & $18.12 \mathrm{a}$ \\
\hline & Mid & $45.58 \mathrm{a}$ & $36.49 \mathrm{a}$ & $45.65 a$ & $35.53 \mathrm{a}$ & $46.67 \mathrm{a}$ & $35.34 \mathrm{a}$ & $2.01 \mathrm{a}$ & $1.88 \mathrm{a}$ & $17.50 \mathrm{a}$ & $16.65 \mathrm{a}$ \\
\hline & Lower & $27.82 \mathrm{~b}$ & $26.87 \mathrm{a}$ & $28.22 \mathrm{~b}$ & $25.71 \mathrm{a}$ & $25.09 \mathrm{~b}$ & $23.78 \mathrm{a}$ & $1.90 \mathrm{a}$ & $1.90 \mathrm{a}$ & $16.43 \mathrm{a}$ & $15.75 \mathrm{a}$ \\
\hline \multirow[t]{3}{*}{ Uirapuru } & Upper & $25.17 \mathrm{~b}$ & $36.00 \mathrm{a}$ & $25.28 \mathrm{~b}$ & $38.08 \mathrm{a}$ & $26.27 b$ & $40.17 \mathrm{a}$ & $1.90 \mathrm{a}$ & $2.14 \mathrm{a}$ & $20.47 \mathrm{a}$ & $\overline{19.01 \mathrm{a}}$ \\
\hline & Mid & $40.48 a$ & $37.23 \mathrm{a}$ & $41.82 \mathrm{a}$ & $36.29 \mathrm{a}$ & $42.14 \mathrm{a}$ & $36.00 \mathrm{ab}$ & $1.97 \mathrm{a}$ & $1.95 \mathrm{a}$ & $19.29 \mathrm{a}$ & $17.74 a$ \\
\hline & Lower & $34.35 \mathrm{a}$ & $26.77 \mathrm{a}$ & $32.90 \mathrm{~b}$ & $25.64 \mathrm{a}$ & $31.59 \mathrm{ab}$ & $23.83 b$ & $1.86 \mathrm{a}$ & $1.88 \mathrm{a}$ & $18.37 \mathrm{a}$ & $16.21 \mathrm{a}$ \\
\hline \multirow[t]{3}{*}{ Pintado } & Upper & $24.61 b$ & $32.91 \mathrm{a}$ & $25.34 b$ & $36.21 \mathrm{a}$ & $27.30 \mathrm{~b}$ & $38.15 \mathrm{a}$ & $2.03 a$ & $2.14 \mathrm{a}$ & $18.73 \mathrm{a}$ & $20.07 a$ \\
\hline & Mid & $43.46 \mathrm{a}$ & $31.58 \mathrm{a}$ & $44.30 \mathrm{a}$ & $30.70 \mathrm{a}$ & $43.69 \mathrm{a}$ & $30.26 \mathrm{a}$ & $2.02 \mathrm{a}$ & $1.87 \mathrm{~b}$ & $17.25 \mathrm{ab}$ & $18.88 \mathrm{ab}$ \\
\hline & Lower & $31.93 \mathrm{~b}$ & $35.51 \mathrm{a}$ & $30.36 \mathrm{~b}$ & $33.09 \mathrm{a}$ & $29.01 \mathrm{~b}$ & $31.59 \mathrm{a}$ & $1.88 \mathrm{a}$ & $1.78 \mathrm{~b}$ & $16.86 \mathrm{~b}$ & $18.40 \mathrm{~b}$ \\
\hline
\end{tabular}

${ }^{(1)}$ Means followed by the same letters in a column do not differ by Tukey's test, at $5 \%$ probability. 


\section{Conclusion}

Using the same gene ahas of BR-16-AHAS in various genotypes, the materials obtained present good tolerance to imazapyr; the tolerance level depends not only on the ahas gene but also on the presence of other genes.

\section{Acknowledgements}

To Coordenação de Aperfeiçoamento de Pessoal de Nível Superior, for scholarship; to Embrapa Soja, for greenhouse facilities; to Carlos Roberto Chagas and Marcelo Soares, for technical help.

\section{References}

ARAGÃO F.J.L.; SAROKIN, L.; VIANNA, G.R.; RECH, E.L. Selection of transgenic meristematic cells utilizing a herbicidal molecule results in the recovery of fertile transgenic soybean [Glycine $\max (\mathrm{L}$.) Merril] plants at a high frequency. Theoretical and Applied Genetics, v.101, p.1-6, 2000.

BEARDMORE R.A.; HART, R.; IVERSON, R.; RISLEY, M.A.; TRIMMER, M. Imazapyr herbicide. In: SHANER, D.L.; O'CONNOR, S.L. (Ed.). The imidazolinone herbicides. Boca Raton: CRS Press, 1991. p.211-227.
FRIZZAS, M.R.; CUNHA, U.S. da; MACEDO, L.P.M. Plantas transgênicas resistentes a insetos. Revista Brasileira de Agrociência, v.10, p.13-18, 2004.

HAIN, R.; SCHREIER, P.H. Genetic engineering in crop protection: opportunities, risks, and controversies. Pflanzenschutz Nachrichten Bayer, v.48, p.25-120, 1995.

HERRERA-ESTRELLA, L. Transgenic plants for tropical regions: some considerations about their development and their transfer to the small farmer. Proceedings of the National Academy of Sciences of the United States of America, v.96, p.5978-5981, 1999.

KIIHL, T.A.M.; ARIAS, C.A.A. Behavior of soybean genotypes transformed with the ahas gene which confers tolerance to herbicide imazapyr. Crop Breeding and Applied Biotechnology, v.4, p.267-272, 2004.

MONQUERO, P.A. Plantas transgênicas resistentes aos herbicidas: situação e perspectivas. Bragantia, v.64, p.517-531, 2005.

PADGETTE, S.R.; KOLACZ, K.H.; DELANNAY, X.; RE, D.B.; LAVALLÉE, B.J.; TINIUS, C.N.; RHODES, W.K.; OTERO, Y.I.; BARRY, G.F.; EICHHOLTZ, D.A.; PESCHKE, V.M.; NIDA, D.L.; TAYLOR, N.B.; KISHORE, G.M. Development, identification and characterization of a glyphosate-tolerant soybean line. Crop Science, v.35, p.1451-1461, 1995.

VARGAS, L.; SILVA, A.A.; BORÉM, A.; REZENDE, S.T.; FERREIRA, F.A.; SEDIYAMA, T. Resistência de plantas daninhas a herbicidas. Viçosa: UFV, 1999. 131p. 